\title{
Biotransformation of grape pomace from Vitis labrusca by Peniophora albobadia LPSC \# 285 (Basidiomycota)
}

\author{
MARÍA I. TRONCOZO, CECILIA B. FIGOLI, MARIO E.E. FRANCO, \\ MARÍA V. MIRÍFICO, ALEJANDRA BOSCH, MARIO RAJCHENBERG, \\ PEDRO A. BALATTI \& MARIO C. N. SAPARRAT
}

\begin{abstract}
Grape pomace from Vitis labrusca is an important sub-product of the "American table wine" industry. It is recalcitrant to degradation, and its accumulation is a serious problem with negative environmental impacts. We analyzed the ability of five white-rot fungi to transform this residue in-vitro. Mass loss and phenol removal in grape pomace treated with each fungus were compared after 30-day solid-state fermentation. Since Peniophora albobadia isolate LPSC 285 was the fungus that showed the highest degradative ability and the lowest free phenol levels in the residue transformed, we selected this fungus to monitor its effect on this residue after 30,60, and 90 days of incubation. We analyzed mass loss of the residue caused by the fungus activity and its chemical changes using Fourier transform infrared spectroscopy. After 90 days of incubation, Peniophora albobadia isolate LPSC 285 reduced grape pomace mass by $20.48 \%$, which was associated with degradation of polysaccharides and aromatic structures. We concluded that Peniophora albobadia LPSC \# 285 isolate is a promising fungus to transform grape pomace from Vitis labrusca under solid-state fermentation conditions.
\end{abstract}

Key words: fungi, grape pomace, Peniophora albobadia, transformation, Vitis labrusca.

\section{INTRODUCTION}

"Cooperativa de la Costa" (Buenos Aires, Argentina) is a small enterprise aimed at producing craft red wine from Vitis labrusca var. Isabella (L) grapes in eastern Buenos Aires province, Argentina (Velarde et al. 2013). This wine was recognized by the National Institute of Vitiviniculture as a regional product with proper sensory features, produced by traditional manufacturing procedures (Resolution No. 23; http:// www.loa.org.ar/legNormaDetalle. aspx?id=23547, Velarde et al. 2013). However, it generates large amounts of organic debris during a short period of time (February and March of each year). This debris is accumulated over long storage intervals without any treatment. This debris accumulation leads to deleterious environmental impacts and phytosanitary risks. One of its most important residues is grape pomace (GP), which is composed of skins and seeds as well as remaining grape pulp. A typical composition of GP is $10.3 \%$ cellulose, $12.0 \%$ hemicellulose, 37.2\% lignin, and a high percentage of moisture $(<75 \%)$. Such subproducts might be used to improve soils by incorporating organic matter and its nutrients for plant growth. However, the skin and seeds contained in this organic waste have a low 
$\mathrm{pH}$ and high levels of phenolic compounds, which are toxic to microorganisms and might also prevent plant growth (Bustamante et al. 2008, Rockenbach et al. 2011). Ferrer et al. (2001), Díaz et al. (2002), Burg et al. (2014), and Dominguez et al. (2014) transformed debris from wine production by processes such as composting and vermicomposting, which stabilize this organic matter, and used it for an agronomic application. However, they represent complex biological processes demanding long processing periods, during which earthworms are highly sensitive to $\mathrm{pH}$, temperature as well as moisture and phenolic compound content (Rostami 2011). Furthermore, while the studies about the revalorization of grape pomace are from different varieties of $V$. vinifera, no studies are available on GP of V. labrusca.

White rot fungi (WRF) are known for their ability to enhance degradation and/or detoxification of a wide variety of agricultural or agro-industrial wastes under solid-state fermentation (SSF), e.g. wheat straw, rice straw, olive mill residue (alpeorujo), and post-harvest sugarcane (Dorado et al. 1999, Maza et al. 2014). The ability of these fungi to transform organic wastes relies on their capacity to release nonspecific oxidative enzymes such as laccases and peroxidases. These enzymes can oxidize and transform lignin and a wide range of structurally similar compounds (Saparrat et al. 2002, 2010b). This biodegradation might be used to treat GP and convert it into a byproduct capable of improving soil conditions, among other applications. To date not much information has been made available regarding fungal transformation of GP (Sanchez et al. 2002, Botella et al. 2007, Vallejo et al. 2012). Therefore, biodegradation of GP of V. labrusca under SSF conditions using WRF is lacking. The aim of this study was to evaluate the feasibility of five selected WRF to degrade GP and reduce its free phenol content. In addition, the transformation of GP by Peniophora albobadia LPSC 285 (Basidiomycota) was evaluated after 30,60, and 90 days under SSF conditions.

\section{MATERIALS AND METHODS}

\section{Grape pomace}

It was collected directly from a basket press available at "Cooperativa de la Costa", an enterprise located in the city of Berisso (Buenos Aires Province, Argentina; latitude 34²3'22.79"S and longitude $57^{\circ} 49^{\prime} 21.11^{\prime \prime} O$ ). All the fresh material collected during the harvest of 2008 (in March) was dried at $60^{\circ} \mathrm{C}$ and representative aliquots of individual samples corresponding to several pressing procedures were used to form a composite pool sample. The material collected was stored for up to 6 months at $25^{\circ} \mathrm{C}$ in a room with moisture levels as low as possible and then used as the substrate for growing the fungi.

\section{Fungal isolates}

Five WRF were used, three belonging to the Aurantiporus genus (two isolates of A. albidus and one of $A$. pulcherrimus), a representative of $P$. albobadia and another of Pycnoporus sanguineus (Table I). Fungal stock cultures were maintained as slants on malt extract agar (MEA) medium at $4{ }^{\circ} \mathrm{C}$. Mycelium plugs (6-mm in diameter) cut from a culture grown on MEA medium were used as inoculum.

\section{Mass loss and phenolic removal in GP by Fungi}

For SSF, 100 mL Erlenmeyer Flasks containing 10 $\mathrm{g}$ of GP (dry mass) and $7 \mathrm{~mL}$ distilled water were sterilized at 121 ㅇ C for 2 periods of 15 min. Flasks were inoculated with three mycelium plugs and incubated at $28 \pm 1.5$ ㅇ C at $70 \%$ relative humidity for 30 days. Uninoculated control flasks were incubated under the same conditions. The experimental design was completely randomized 
Table I. White-rot fungi used in this study.

\begin{tabular}{|c|c|c|}
\hline \multicolumn{1}{|c|}{ Species } & Isolate & Reference \\
\hline Aurantiporus pulcherrimus (Rodway) P.K. Buchanan \& Hood & CIEFAP 80 & Hood et al. 2008 \\
\hline Aurantiporus albidus Rajchenb. \& Cwielong & CIEFAP 111 & Rajchenberg and Robledo 2013 \\
\hline Aurantiporus albidus Rajchenb. \& Cwielong & CIEFAP 117 & Rajchenberg and Robledo 2013 \\
\hline Pycnoporus sanguineus (L:Fr.) Murr. & LPSC 163 & Saparrat et al. 2002 \\
\hline Peniophora albobadia (Schw.: Fr.) Boidin & LPSC 285 & Saparrat et al. 2002 \\
\hline
\end{tabular}

${ }^{a}$ Mycological herbarium at Centro Forestal Andino Patagónico. Chubut, Argentina. ${ }^{b}$ Culture collection of Instituto Spegazzini, La Plata. Buenos Aires, Argentina.

with three replicates per treatment. Percentage of mass reduction of inoculated GP in relation to the uninoculated one was assessed according to Saparrat et al. (2010a). A water soluble fraction (WSF) from uninoculated and inoculated GP was obtained according to Saparrat et al. (2008), and its phenolic concentration was estimated (Saparrat et al. 2010a).

\section{Time course of GP transformation by $P$. albobadia LPSC 285}

The fungus was cultivated on GP under SSF conditions as described above for 30,60 , and 90 days of incubation. Uninoculated sterilized GP was incubated under the same conditions and used as an abiotic control. The experimental design was completely randomized, and three independent replicates were carried out for each time of incubation, with a solid fraction (SF) and a WSF obtained from both uninoculated and fungal transformed GP, according to Saparrat et al. (2008). On SFs, the percentage of mass reduction of inoculated GP in relation to the uninoculated one was estimated, and its chemical composition was studied using Fourier transform infrared (FT-IR) spectroscopy, according to Saparrat et al. (2010a). Decay rate (k) of GP, both inoculated and uninoculated, was estimated using an exponential decay model (Mallerman et al. 2018). In the WSF of uninoculated and inoculated GP, concentration of ammonium-nitrogen $\left(\mathrm{NH}_{4}{ }^{+} \mathrm{N}\right.$; Saparrat et al. 2010a), total soluble reducing carbohydrates (TSRC; Saparrat et al. 2008), pH, and phenolics as well as the polymerization/polydispersity index (the ratio of optical density at $465 \mathrm{~nm}$ to that at $665 \mathrm{~nm}$; Dorado et al. 1999) were determined. Also, the activity of $\beta-1,4$ endoglucanase (E.C. 3.2.1.4), laccase (EC 1.10.3.2) and peroxidase (EC 1.11.1.7) on the WSF obtained from fungal treated GP was determined. The activity of the $\beta-1,4-$ endoglucanase was estimated by measuring the amount of reducing cellooligosaccharides released from sodium-carboxy-methylcellulose (BDH Chemicals Ltd; Saparrat et al. 2008). Laccase activity was measured using 2,2-azinobis (3-ethylbenzothiazoline-6-sulphonic acid) (Sigma-Aldrich) according to Saparrat et al. (2008). Peroxidase activity was estimated using 2,6-dimethoxyphenol (Fluka) as substrate in the presence of $0.1 \mathrm{mM} \mathrm{H}_{2} \mathrm{O}_{2}$ (Saparrat et al. 2008).

\section{FT-IR Spectroscopy}

For sample preparation, each SF from GP treated with P. albobadia for 30,60 , and 90 days and the corresponding uninoculated GP as well as an additional one at time zero (immediately after the sterilization) were dried at $60^{\circ} \mathrm{C}$. Each sample was homogenized with an agate mortar and sieved through $<0.63 \mathrm{~mm}$ screen. Each 
resultant powder was embedded in $\mathrm{KBr} 13-\mathrm{mm}$ pellets ( $2 \mathrm{mg}$ of sample and $20 \mathrm{mg}$ of infraredgrade $\mathrm{KBr}$ ). FTIR absorption/transmission $(A / T)$ spectra between 4,000 and $650 \mathrm{~cm}^{-1}$ were acquired using a Thermo Nicolet Nexus 470 spectrometer (Thermo-Electric Corporation, Chicago, IL, USA) with $4 \mathrm{~cm}^{-1}$ spectral resolution and 64 scan co-additions. To avoid interference of spectral water vapor bands, the spectra were measured under continuous purge of dried air. Two technical replicates were performed for each sample. Before data analysis, the whole set of spectra was subjected to a spectral pre-processing procedure. Briefly, technical replicates were averaged, and first and second derivatives were calculated using the SavitzkyGolay algorithm with 13-point smoothing and then vector normalized in the full spectral range using OPUS software (versions 7.0 Bruker Optics GmbH, Ettlingen, Germany; Naumann 2000). Bands selected as index peaks reflecting functional groups associated with the cell walls were assigned (Table II). The peak area at 904 $\mathrm{cm}^{-1}\left(A_{904}\right)$, which was assigned to the $\beta$-glycosidic content, and the peak area at $1262 \mathrm{~cm}^{-1}\left(A_{1262}\right)$, which was assigned to skeletal ring vibrations of lignin and used as an internal standard of the total biomass content, were calculated (Naumann 2000). The semi-quantitative evaluation of the $\beta$-glycosidic bond along the GP treatment was calculated according to the equation $\alpha=A_{904} / A_{1262}$ (OPUS software, versions 7.0 Bruker Optics GmbH, Ettlingen, Germany).

\section{Statistical analysis}

Data corresponding to mass loss and phenolic removal in GP by fungi as well as enzyme levels of P. albobadia LPSC 285 during culture time were analyzed by means of a one-way analysis of variance (ANOVA). The means of the treatments were contrasted using the Tukey's Test ( $p \leq 0.05$; Statistix 8.0). Values of the $A_{904} / A_{1262}$ ratio were

Table II. Assignment of FT-IR bands corresponding to functional groups.

\begin{tabular}{|c|c|c|c|}
\hline $\begin{array}{c}\text { Window } \\
\text { Spectral regions } \\
\left(\mathrm{cm}^{-1}\right)\end{array}$ & $\begin{array}{c}\text { FTIR } \\
\text { frequency } \\
\left(\mathrm{cm}^{-1}\right)\end{array}$ & Assignment $^{a}$ & References \\
\hline & 3010 & $\mathrm{C}-\mathrm{H}$ def. in the plane of the aromatic ring in lignin & Stuart \& Ando 1997 \\
\hline & 2958 & $\mathrm{C}-\mathrm{H}$ asym. str. of $-\mathrm{CH}_{3}$ in fatty acid chains & $\begin{array}{l}\text { Stuart \& Ando 1997, } \\
\text { Naumann } 2000\end{array}$ \\
\hline \multirow{3}{*}{$\begin{array}{c}\text { W1 } \\
\text { Lipids } \\
3,000-2,800\end{array}$} & 2924 & $\mathrm{C}-\mathrm{H}$ asym. str. of $>\mathrm{CH}_{2}$ in fatty acid chains & $\begin{array}{l}\text { Stuart \& Ando 1997, } \\
\text { Naumann } 2000\end{array}$ \\
\hline & 2873 & $\mathrm{C}-\mathrm{H}$ sym. str. of $-\mathrm{CH}_{3}$ in fatty acids & $\begin{array}{l}\text { Stuart \& Ando 1997, } \\
\text { Naumann } 2000\end{array}$ \\
\hline & 2853 & $\mathrm{C}-\mathrm{H}$ sym. str. of $>\mathrm{CH}_{2}$ in fatty acids & $\begin{array}{l}\text { Stuart \& Ando 1997, } \\
\text { Naumann } 2000\end{array}$ \\
\hline \multirow{3}{*}{$\begin{array}{c}\text { W2 } \\
\text { Amide I and II } \\
1,800-1,480\end{array}$} & $\begin{array}{l}1744 \\
1715\end{array}$ & $\mathrm{C}=\mathrm{O}$ str. of $\mathrm{COOCH}_{3}$ and $\mathrm{COOH}$ groups in pectin & $\begin{array}{c}\text { Batsoulis et al. 2004, } \\
\text { Kyomugasho et al. 2015, } \\
\text { Leão et al. } 2018\end{array}$ \\
\hline & $\begin{array}{l}\text { Amide I } \\
1651\end{array}$ & $\begin{array}{c}>C=O \text { str. and } C-N \text { ben. of protein and peptides } \\
\text { amide. Sensitive to protein conformation }\end{array}$ & $\begin{array}{l}\text { Stuart \& Ando 1997, } \\
\text { Batsoulis et al. } 2004\end{array}$ \\
\hline & $\begin{array}{l}\text { Amide II } \\
1540\end{array}$ & $\mathrm{~N}-\mathrm{H}$ ben., $\mathrm{C}-\mathrm{N}$ str. of proteins and peptides & $\begin{array}{l}\text { Stuart \& Ando 1997, } \\
\text { Batsoulis et al. } 2004\end{array}$ \\
\hline
\end{tabular}


Table II (continuation)

\begin{tabular}{|c|c|c|c|}
\hline $\begin{array}{c}\text { Window } \\
\text { Spectral regions } \\
\left(\mathrm{cm}^{-1}\right)\end{array}$ & $\begin{array}{c}\text { FTIR } \\
\text { frequency } \\
\left(\mathrm{cm}^{-1}\right)\end{array}$ & Assignment $^{a}$ & References \\
\hline \multirow{7}{*}{$\begin{array}{c}\text { W3 } \\
\text { Mixed Region } \\
1,480-1,250\end{array}$} & $\begin{array}{r}1470 \\
1450\end{array}$ & $\begin{array}{c}\mathrm{CH}_{2} \text { sym. scissoring of pyran ring in hemicellulose } \\
\text { and cellulose }\end{array}$ & $\begin{array}{l}\text { Schwanninger et al. } \\
\text { 2004, Popescu et al. 2010, } \\
\text { Heredia-Guerrero et al. } \\
2014\end{array}$ \\
\hline & 1416 & $\mathrm{CH}_{2}$ scissoring of cellulose & $\begin{array}{l}\text { Schwanninger et al. 2004, } \\
\text { Carballo-Meilan et al. } 2014\end{array}$ \\
\hline & 1377 & $\mathrm{CH}_{3}$ def. in the plane of carbohydrates & $\begin{array}{l}\text { Pandey \& Pitman 2003, } \\
\text { Boeriu et al. 2004, } \\
\text { Schwanninger et al. 2004, } \\
\text { Popescu et al. } 2010\end{array}$ \\
\hline & 1340 & C-O str. of syringyl unit of lignin & $\begin{array}{l}\text { Pandey \& Pitman 2003, } \\
\text { Popescu et al. 2010, } \\
\text { Saparrat et al. 2010a }\end{array}$ \\
\hline & 1310 & $\mathrm{CH}_{2}$ wagging of cellulose & $\begin{array}{l}\text { Schwanninger et al. 2004, } \\
\text { Carballo-Meilan et al. } 2014\end{array}$ \\
\hline & 1264 & C-O str. of guaiacyl unit of lignin & $\begin{array}{l}\text { Pandey \& Pitman 2003, } \\
\text { Popescu et al. 2010, } \\
\text { Saparrat et al. 2010a }\end{array}$ \\
\hline & 1241 & $\begin{array}{c}\text { C-O str. of phenols groups of aromatics rings in } \\
\text { syringyl and guaiacyl groups }\end{array}$ & Popescu et al. 2010 \\
\hline \multirow{9}{*}{$\begin{array}{c}\text { W4 } \\
\text { Carbohydrates } \\
1,200-900 \\
900-700\end{array}$} & 1135 & $\mathrm{C}-\mathrm{H}$ def. in the plane in the guaiacyl ring & $\begin{array}{l}\text { Kacuráková et al. 2000, } \\
\text { Schwanninger et al. } 2004\end{array}$ \\
\hline & 1117 & $\mathrm{C}-\mathrm{C}$ and $\mathrm{C}-\mathrm{O}$ str. in pectin & $\begin{array}{l}\text { Batsoulis et al. 2004, } \\
\text { Kyomugasho et al. 2015, } \\
\text { Leã̃o et al. } 2018\end{array}$ \\
\hline & 1106 & $\begin{array}{l}\mathrm{COH} \text { def. in the plane in hemicellulose and } \\
\text { cellulose }\end{array}$ & $\begin{array}{l}\text { Boeriu et al. 2004, } \\
\text { Schwanninger et al. 2004, } \\
\text { Popescu et al. } 2010\end{array}$ \\
\hline & $\begin{array}{l}1076 \\
1066\end{array}$ & $\begin{array}{l}\text { C-O-C vibrations of arabinogalactan and } \\
\text { glucomannan of hemicellulose }\end{array}$ & Kacuráková et al. 2000 \\
\hline & 1033 & $\mathrm{C}-\mathrm{H}$ def. in the plane of the aromatic ring in lignin & Stuart \& Ando 1997 \\
\hline & 904 & $\alpha$-glycosidic linkages & $\begin{array}{l}\text { Kacuráková et al. 2000, } \\
\text { Synytsya et al. 2003, } \\
\text { Popescu et al. 2010 }\end{array}$ \\
\hline & 877 & $\mathrm{C}-\mathrm{H}$ def. in the plane of the aromatic ring in lignin & Dokken et al. 2002 \\
\hline & 842 & $\beta$-glycosidic linkages & $\begin{array}{l}\text { Kacuráková et al. 2000, } \\
\text { Synytsya et al. 2003, } \\
\text { Popescu et al. } 2010\end{array}$ \\
\hline & 789 & $\mathrm{C}-\mathrm{OH}$ ring str. of pectin & $\begin{array}{l}\text { Batsoulis et al. 2004, } \\
\text { Kyomugasho et al. 2015, } \\
\text { Leão et al. } 2018\end{array}$ \\
\hline
\end{tabular}


Table II (continuation)

\begin{tabular}{|c|c|c|c|}
\hline $\begin{array}{c}\text { Window } \\
\text { Spectral regions } \\
\left(\mathrm{cm}^{-1}\right)\end{array}$ & $\begin{array}{c}\text { FTIR } \\
\text { frequency } \\
\left(\mathrm{cm}^{-1}\right)\end{array}$ & Assignment $^{a}$ & References \\
\hline \multirow{9}{*}{$\begin{array}{c}\text { W4 } \\
\text { Carbohydrates } \\
1,200-900 \\
900-700\end{array}$} & 1135 & $\mathrm{C}-\mathrm{H}$ def. in the plane in the guaiacyl ring & $\begin{array}{l}\text { Kacuráková et al. 2000, } \\
\text { Schwanninger et al. } 2004\end{array}$ \\
\hline & 1117 & $\mathrm{C}-\mathrm{C}$ and $\mathrm{C}-\mathrm{O}$ str. in pectin & $\begin{array}{c}\text { Batsoulis et al. 2004, } \\
\text { Kyomugasho et al. 2015, } \\
\text { Leão et al. } 2018\end{array}$ \\
\hline & 1106 & $\begin{array}{c}\mathrm{COH} \text { def. in the plane in hemicellulose and } \\
\text { cellulose }\end{array}$ & $\begin{array}{l}\text { Boeriu et al. 2004, } \\
\text { Schwanninger et al. } 2004, \\
\text { Popescu et al. } 2010\end{array}$ \\
\hline & $\begin{array}{l}1076 \\
1066\end{array}$ & $\begin{array}{l}\text { C-O-C vibrations of arabinogalactan and } \\
\text { glucomannan of hemicellulose }\end{array}$ & Kacuráková et al. 2000 \\
\hline & 1033 & $\mathrm{C}-\mathrm{H}$ def. in the plane of the aromatic ring in lignin & Stuart \& Ando 1997 \\
\hline & 904 & $\alpha$-glycosidic linkages & $\begin{array}{l}\text { Kacuráková et al. 2000, } \\
\text { Synytsya et al. 2003, } \\
\text { Popescu et al. 2010 }\end{array}$ \\
\hline & 877 & $\mathrm{C}-\mathrm{H}$ def. in the plane of the aromatic ring in lignin & Dokken et al. 2002 \\
\hline & 842 & $\beta$-glycosidic linkages & $\begin{array}{l}\text { Kacuráková et al. 2000, } \\
\text { Synytsya et al. 2003, } \\
\text { Popescu et al. 2010 }\end{array}$ \\
\hline & 789 & $\mathrm{C}-\mathrm{OH}$ ring str. of pectin & $\begin{array}{c}\text { Batsoulis et al. 2004, } \\
\text { Kyomugasho et al. 2015, } \\
\text { Leão et al. } 2018\end{array}$ \\
\hline
\end{tabular}

a(asym.) asymmetric; (sym.) symmetric; (str.) stretching; (ben.) bending; (def.) deformation.

analyzed by one-way ANOVA, and a Fisher's least significant difference (LSD) procedure was applied to compare means $(p<0.05)$. A two-way nested ANOVA with two main effects, "treatment type" (uninoculated GP versus inoculated GP) and "incubation time", was applied to several physico-chemical parameters measured on the WSF obtained from GP untreated and treated with P. albobadia LPSC 285 at different incubation times. A Principal Component Analysis (PCA) was performed using PyChem software (versions 3.0.5 geta) and, as input data, the first derivative of vector normalized data in the spectral regions 3000-2800, 15001250 and $1200-750 \mathrm{~cm}^{-1}$ (Naumann 2000, Jarvis et al. 2006).

\section{RESULTS}

Although all fungi reduced the GP mass and its phenolic content, P. albobadia LPSC 285 showed the highest degradative ability (Fig. 1). During 90 incubation days, this fungus reduced the GP mass by $20.48 \%$ to a rate of 0.002 g.day $^{-1}$, compared to that of the uninoculated residue (Fig. 2).

To further study the effect of P. albobadia LPSC 285 on GP, we monitored the transformations that took place in the residue over time (30, 60, 90 days) by A/T FTIR spectroscopy. Figure 3 shows absorbance FTIR spectra of fungal treated and untreated GP at time zero (immediately after the sterilization) and their corresponding second derivative vector normalized spectra at four main spectral windows. These windows 

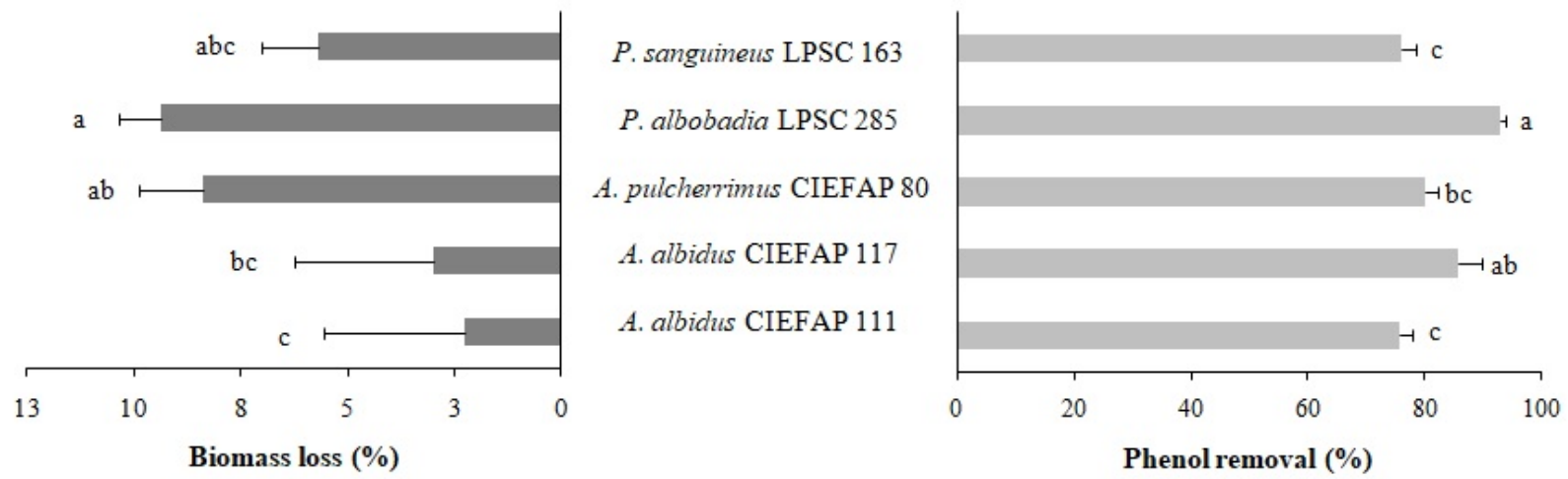

Figure 1. Biomass loss and phenol removal (\%) of GP by WRF at 30 days. Means \pm SD (bars) followed by the same letter are not significantly different according to Tukey's test, $\mathrm{p}<0.05$.

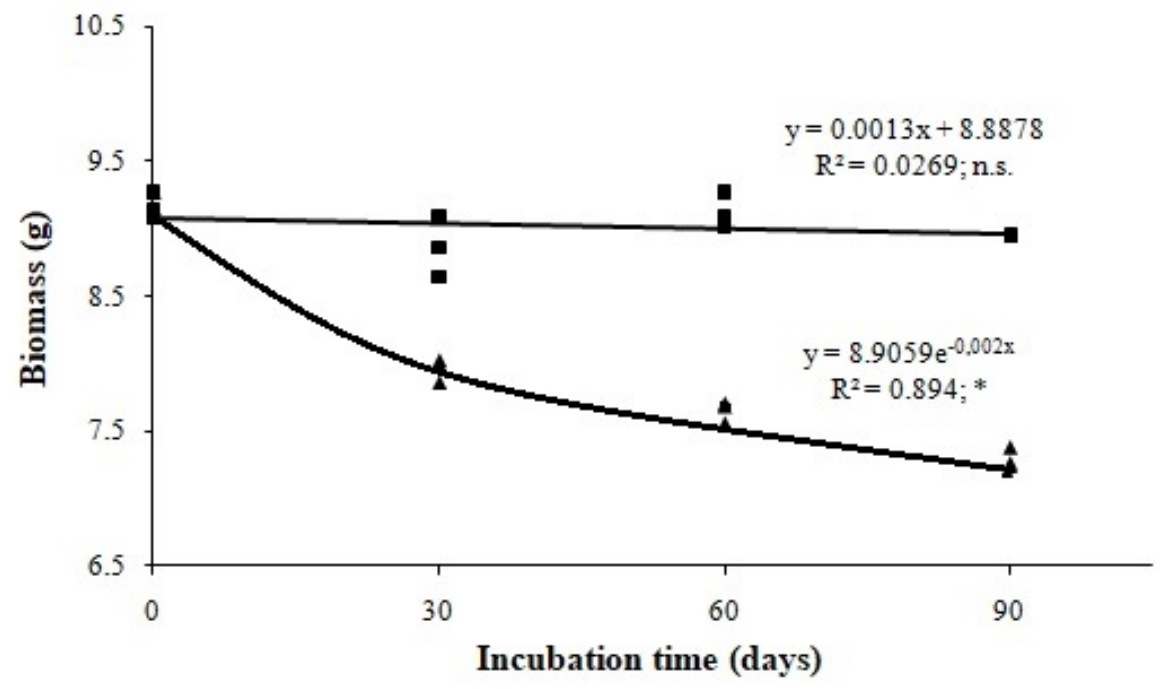

Figure 2. Regression analysis between biomass of GP uninoculated ( $\square$ ) and inoculated $(\Delta)$ with Peniophora albobadia LPSC 285 and incubation time. Linear regression equation, $F$ test significance $(p)$ and coefficients of determination $\left(R^{2}\right)$ are presented. (ns) Not significant; $\left({ }^{*}\right) p<0.05$.

were as follows: W1 (2800-3000 $\left.\mathrm{cm}^{-1}\right)$, associated with lipids and presenting bands assigned to the anti-symmetric and symmetric stretching of $>\mathrm{CH}_{3}$ detected at 2958 and $2873 \mathrm{~cm}^{-1}$, respectively, and the anti-symmetric and symmetric stretching modes for the $>\mathrm{CH}_{2}$ observed at 2924 and $2853 \mathrm{~cm}$ 1, respectively; W2 (1800-1480 $\left.\mathrm{cm}^{-1}\right)$, representing the typical amide I band at $1651 \mathrm{~cm}^{-1}$, mainly due to $>\mathrm{C}=\mathrm{O}$ absorptions, and amide $\|$ bands at $1540 \mathrm{~cm}^{-1}$, assigned to the $\mathrm{N}--\mathrm{H}$ bending with contributions of the $\mathrm{C}-\mathrm{N}$ stretching vibrations in proteins; W3 (1480-1250 $\left.\mathrm{cm}^{-1}\right)$, a mixed region presenting spectral peaks from $\mathrm{C}-\mathrm{H}$ deformation $\left(1377 \mathrm{~cm}^{-1}\right)$ and $\mathrm{C}-\mathrm{O}$ stretching $(1264,1241$ and $1215 \mathrm{~cm}^{-1}$ ) corresponding to carbohydrates, as well as $>\mathrm{C}-\mathrm{O}$ and $>\mathrm{P}=\mathrm{O}$ symmetric stretching corresponding to fatty acid, proteins and lipids; and W4 (1250-900 $\left.\mathrm{cm}^{-1}\right)$, showing bands that hold the peaks assigned to carbohydrate modes and side groups $\mathrm{C}-\mathrm{O}-\mathrm{C}, \mathrm{C}-\mathrm{C}$ and $\mathrm{C}-\mathrm{O}$. 


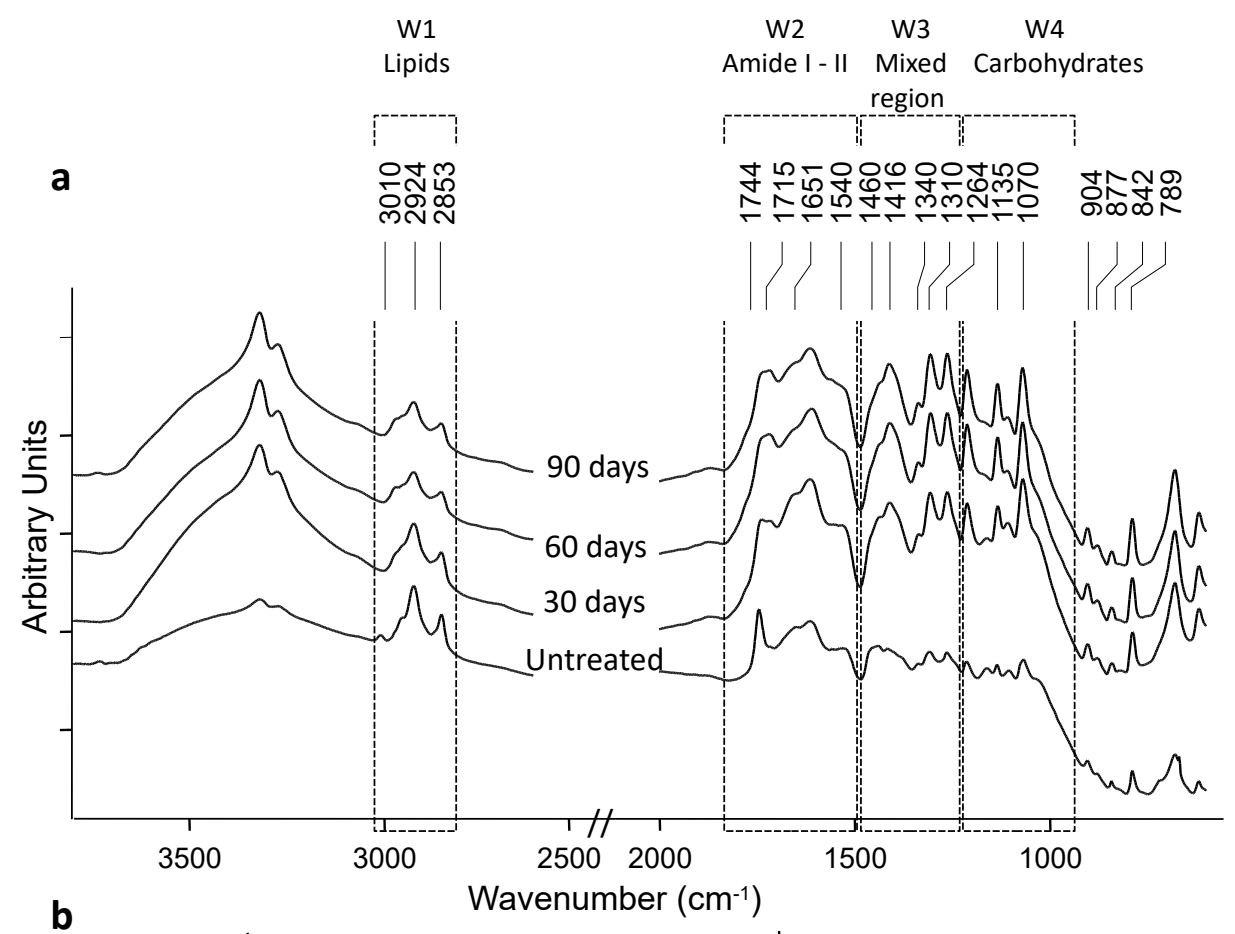

A

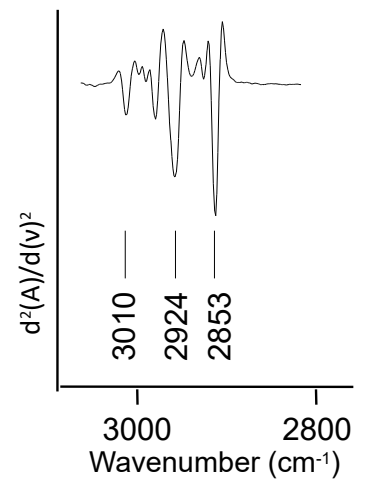

C

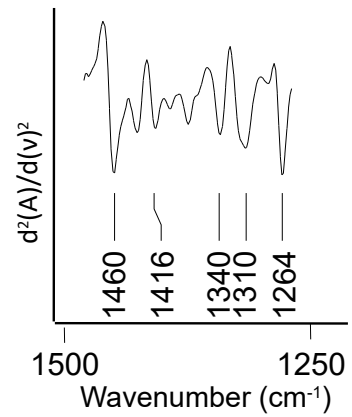

B
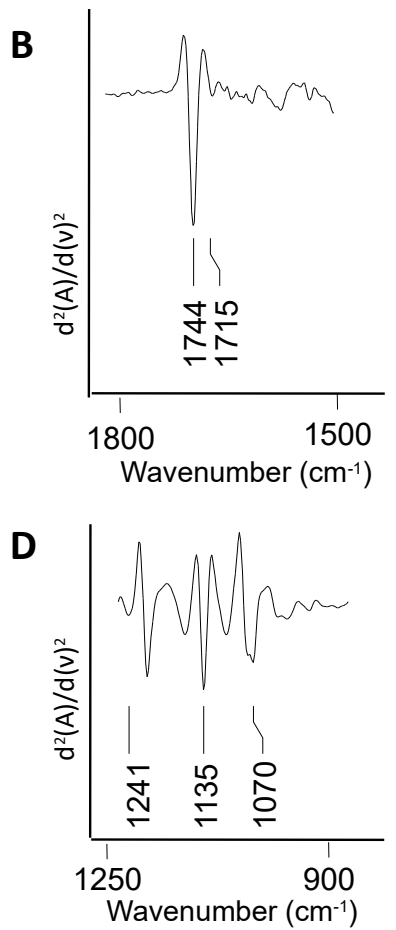

Figure 3. FT-IR absorption spectra of GP untreated and treated with P. albobadia LPSC 285 at several incubation times. (a) Four average spectra obtained from three independent experiments corresponding to the GP treated with P. albobadia LPSC 285 at several incubation times (30,60, and 90 days) and uninoculated GP at time zero of incubation (immediately after the sterilization). Spectral windows associated with functional groups in biomolecules are indicated (W1 to W4). (b) Vector-normalize second-derivative of spectral windows associated with (A) lipids-W1 $\left(3,000-2,800 \mathrm{~cm}^{-1}\right)$, (B) W2 assigned to protein absorptions $\left(1,800-1,500 \mathrm{~cm}^{-1}\right)$, (C) W3-mixed regions $\left(1,500-1,200 \mathrm{~cm}^{-1}\right),(D)$ W4 assigned to carbohydrates $\left(1,200-900 \mathrm{~cm}^{-1}\right)$. 
In addition, two bands sensitive to anomeric configuration assigned to $\alpha$ and $\beta$-glycosidic linkages in the region $900-800 \mathrm{~cm}^{-1}$ (904 and 842 $\mathrm{cm}^{-1}$ respectively) were observed. Specifically, a reduction in the level of $\beta-1,4$ glycosidic bonds resulted from the fungal activity, although it did not vary during the whole incubation period (Table III). In addition, absorbance FTIR spectra of uninoculated GP during 90 incubation days only showed some slight alterations in functional groups related to lignin-like aromatic polymers such as phenolic groups seen at $1241 \mathrm{~cm}^{-1}$ (data not shown). To better visualize the differences in the chemical modifications of GP by Peniophora albobadia, a PCA was applied (Fig. 4). The score-plot for PC2 and PC3 showed that the GP samples were distributed from left to right of PC2 axis according to the exposure time to the fungus. Interestingly, samples treated with the fungus for 90 days grouped separately from the rest (Fig. 4a). Bands corresponding to cellulose, hemicelluloses, and lignin proved to be spectral features that explained this discrimination, such as that analyzed in the loading plot (Fig 4b).

Different assays on the WSF of uninoculated and inoculated GP were performed. Only $\beta-1,4$ endoglucanase activity was found in WSF of inoculated GP, which did not vary during the whole incubation period $\left(25.22 \pm 6.10 \mathrm{mU} \cdot \mathrm{ml}^{-1}\right.$, $p>0.05)$. In addition, the fungus modified several chemical parameters in the WSF, which presented a differential behavior (Table IV). Although some reduction in the free phenol content in WSF was observed in uninoculated GP after 90 incubation days, the fungus reduced the level of free phenols and TSRC in WSF during the whole incubation period. Compared to control $G P$, the $E_{4} / E_{6}$ ratio in WSF showed higher levels only in the 30-60 day period. However, similar $E_{4} / E_{6}$ ratios were found for both inoculated and uninoculated GP at 90 incubation days. Besides, ammonium and $\mathrm{pH}$ levels in WSF increased after 60 days in the presence of the fungus.

\section{DISCUSSION}

GP is a solid waste from the winemaking process that has a complex chemical composition. It containsgrape peeland seedsaswellas remaining pulp, in which cellulose, hemicelluloses, lignin, and pectin as well as soluble compounds such as phenolics and sugars are present in different proportions (Guerra-Rivas et al. 2017). The chemical composition of grapes and their residues produced in the wine industry varies among different Vitis species and the cultivar type, and other factors including the soil where the plant grows, the cultivation conditions, the stage of maturity, and the winemaking process (Guerra-Rivas et al. 2017, Schaffer et al. 2016). Compared to $V$. vinifera wine, the sensory characteristics from wine made from $V$. labrusca grapes have been associated with the content of several compounds such as flavonoids, organic acids and volatile phenols, which influence the color, flavor, bitterness, and astringency of wine (Ivanova-Petropulos et al. 2015, Arcanjo et al. 2017). Since Rizzon et al. (2000) reported that the skin of the Isabella grape yields a higher concentration of organic acids than that of $V$. vinifera cultivars, possibly due to the release of organic acids during maceration, the high concentration of these acids in GP using $V$. labrusca might in turn condition the selection of biological agents to reduce the wastes generated during the winemaking at Cooperativa del vino de la Costa (Argentina). Among the organisms involved in the revalorization of organic wastes, fungi, specifically WRF, have been reported to play a greater role than bacteria due to their ability to degrade severely recalcitrant plant polymers and several toxic simple compounds, 

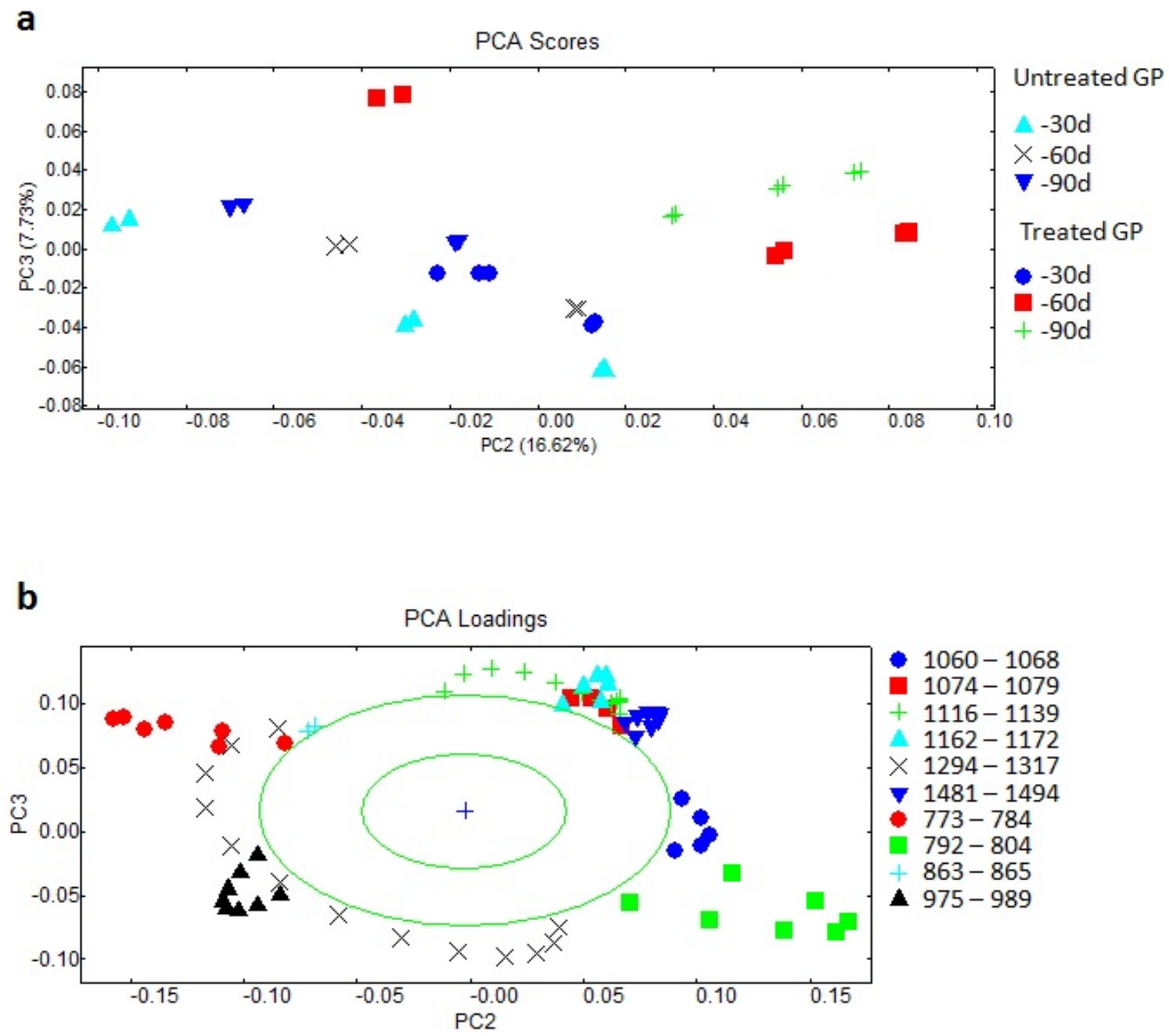

Figure 4. PCA of FT-IR average spectra of GP untreated and treated with P. albobadia LPSC 285 at several incubation times (30,60, and 90 days). PCA was carried out with vector-normalized first-derivative spectra of three independent replicates of each treatment in the spectral range of W1 $\left(3000-2800 \mathrm{~cm}^{-1}\right)$, W3 $\left(1500-1250 \mathrm{~cm}^{-1}\right)$, and W4 (1200-750 cm $\mathrm{cm}^{-1}$ ). (a) PCA score plot. (b) PCA loading.

such as phenolic compounds, as well as their ability to recycle nitrogen from endogenous sources more efficiently than bacteria (Hodge et al. 2000). Five WRF were used for treating GP from V. labrusca under SSF axenic conditions. These WRF are known as efficient lignin degraders of the natural woody substrates from where they are isolated, but there are no data about their degrading ability on wastes from Vitis spp. Although these fungi can degrade in-vitro GP and its components such as free phenolic compounds, they reduced GP mass differently among the tested fungi. This difference can be due, at least in part, to the ability of these fungi to detoxify inhibiting compounds and/ or to synthetize different systems of lignocellulolytic enzymes. However, here we only selected P. albobadia LPSC 285 to monitor its potential in the transformation of GP under SSF conditions since it caused the highest substrate mass loss and removal of free phenols after 30 days of growth. Previous reports have shown 
Table III. Semi-quantitative determination of $\beta$-glycosidic bonds in Peniophora albobadia-treated and untreated GP at different incubation times evaluated by FT-IR spectroscopy.

\begin{tabular}{|c|c|c|}
\hline \multirow[b]{2}{*}{$\begin{array}{l}\text { Culture time } \\
\text { (days) }\end{array}$} & \multicolumn{2}{|c|}{$\alpha=A_{904} / A_{1262}$} \\
\hline & UT & $\mathbf{T}$ \\
\hline 30 & $0.34 \pm 0.05 a$ & $0.28 \pm 0.02 b$ \\
\hline 60 & $0.32 \pm 0.01 a$ & $0.26 \pm 0.02 b$ \\
\hline 90 & $0.33 \pm 0.02 a$ & $0.25 \pm 0.05 b$ \\
\hline
\end{tabular}

( $\alpha$ ) Relative absorbance ratio for band area at $904 \mathrm{~cm}^{-1}$ ( $\beta$-glucosidic bonds) and the area at $1262 \mathrm{~cm}^{-1}$ (C-O stretching of guaiacyl unit of lignin). Data followed by the same letter are not significantly different (Tukey's, $p<$ 0.05). (UT) Untreated; (T) treated.

Table IV. Time course of transformation of GP untreated (UT) and treated (T) with Peniophora albobadia LPSC 285: physico-chemical parameters measured on the WSF.

\begin{tabular}{|c|c|c|c|c|c|c|}
\hline \multirow{2}{*}{$\begin{array}{c}\text { Physico- } \\
\text { chemical } \\
\text { parameters }\end{array}$} & \multicolumn{2}{|c|}{30 days $^{d}$} & \multicolumn{2}{|c|}{60 days } & \multicolumn{2}{|c|}{90 days } \\
\hline & UT & $\mathbf{T}$ & UT & $\mathbf{T}$ & UT & $\mathbf{T}$ \\
\hline $\mathrm{pH}$ & $3.67^{\mathrm{a}} \pm 0.01 c$ & $3.84 \pm 0.02 b$ & $3.62 \pm 0.03 c$ & $4.18 \pm 0.07 a$ & $3.63 \pm 0.06 c$ & $4.10 \pm 0.02 a$ \\
\hline $\begin{array}{l}\text { Phenolics } \\
\left(\mathrm{mg} .100 \mathrm{ml}^{-1}\right)\end{array}$ & $37.24 \pm 3.72 \mathrm{a}$ & $5.97 \pm 0.82 d$ & $23.59 \pm 1.78 b$ & $5.50 \pm 0.61 d$ & $15.05 \pm 3.95 c$ & $5.35 \pm 1.05 d$ \\
\hline $\begin{array}{c}\mathrm{NH}_{4}^{+}-\mathrm{N} \\
\left(\mathrm{mg} .100 \mathrm{ml}^{-1}\right)\end{array}$ & $14.34 \pm 2.68 b$ & $12.66 \pm 2.67 b$ & $25.5 \pm 3.32 b$ & $105.80 \pm 18.20 \mathrm{a}$ & $19.40 \pm 3.50 b$ & $108.59 \pm 21.47 a$ \\
\hline $\operatorname{TRSC}^{\mathrm{b}}(\mathrm{mM})$ & $4.64 \pm 0.32 \mathrm{a}$ & $1.66 \pm 0.16 b$ & $4.05 \pm 1.00 \mathrm{a}$ & $0.77 \pm 0.21 b$ & $3.31 \pm 0.34 \mathrm{a}$ & $0.56 \pm 0.12 b$ \\
\hline $\mathrm{E}_{4} / \mathrm{E}_{6}{ }^{\mathrm{c}}$ & $5.83 \pm 0.22 c$ & $12.33 \pm 0.79 a$ & $4.51 \pm 0.66 c$ & $12.89 \pm 0.59 a$ & $9.24 \pm 0.57 b$ & $8.43 \pm 0.22 b$ \\
\hline
\end{tabular}

${ }^{a}$ Mean and standard deviation of three biological replicates. Data followed by the same letter are not significantly different (Tukey's test, $p<0.05$ ). ${ }^{b}(T R S C)$ Total soluble reducing carbohydrates. ${ }^{c}(E 4 / E 6)$ Polydispersion index calculated as Abs. $465 \mathrm{~nm}{ }^{*}$ Abs. $665 \mathrm{~nm}^{-1}$ ratio. ${ }^{\mathrm{d}}(\mathrm{UT})$ Untreated; (T) treated.

the outstanding ability of P. albobadia to attack wood and several of its components (Saparrat et al. 2000, 2002, Speranza et al. 2009). In the first period of incubation time (30 days), P. albobadia LPSC 285 showed the highest reduction in free phenols and TSRC available in WSF from GP. This high reduction was possibly due to the need to detoxify available phenols and use simple sugars as a source of energy and C, without modifying the ammonium nitrogen level in
WSF because the fungus re-cycles the $\mathrm{N}$ upon mycelial autolysis. Similar results were found by analyzing cultures of other WRF grown on wheat straw, alpeorujo, and grape stalk (Dorado et al. 1999, Arienzo et al. 2003, Levin et al. 2012). Then, at 60 days, fungal-treated GP showed a higher amount of ammonium in WSF than the untreated one, which shows the fungus ability to mineralize organic N from GP. Nitrogen in wine pomace is mainly incorporated into proteins (6-15\%, dry 
matter), which are apparently covalently linked to polysaccharides in skin and seed (Toaldo et al. 2013, García-Lomillo \& Gonzalez-San José 2017). In addition, the increase in ammonium content in WSF during the fungal transformation might be associated with the increase in $\mathrm{pH}$ in the WSF from GP. Therefore, the chemical mechanism behind the little rise in $\mathrm{pH}$ by GP treated by the fungus might be, at least in part, related to nitrogen metabolism.

FTIR spectroscopy has been used to characterize the chemistry of wood and determine the lignin content in pulp, paper and wood (Popescu et al. 2009). It has also been applied to analyze the chemical changes occurring during wood weathering, decay, and chemical treatments or natural ageing (Popescu et al. 2006). Several studies have used different spectroscopic technologies to analyze the fungal decay of wood (Pandey \& Pitman 2003, Popescu at al. 2010). Since the interference of water vapor bands did not allow us to perform the FTIR analysis of protein bands in GP, future studies are needed to confirm if $P$. albobadia LPSC 285 has the ability to degrade GP proteins and to determine whether the proteins are the main source for the alkalinization processes mediated by this fungus. Nevertheless, this work represents the first detailed FT-IR spectroscopic analysis to monitor the chemical composition changes occurring during the treatment of GP by a white-rot fungus such as P. albobadia LPSC 285 isolate. Through this type of analysis, we detected a lower relative concentration of $\beta$-glycosidic bond in fungal treated GP, compared to the uninoculated one. This, together with the detection of $\beta-1,4$ endoglucanase activity in the WSF, confirmed that the fungus has the ability to degrade holocellulose. However, the activity of this enzyme and the level of the $\beta$-glycosidic bond in treated GP did not vary over time, which is compatible with the main action of the fungus degrading GP and its components on the first 30 days of incubation. Botella et al. (2007) also used GP as growth substrate to produce hydrolytic enzymes by Aspergillus awamori. Among extracellular oxidative enzymes, laccases and peroxidases are those mainly related to transformation of phenolics (Saparrat et al. 2010b). However, no activity of oxidative enzymes was found in WSF. These enzymes in P. albobadia LPSC 285, which were previously reported when the fungus was cultured on agar and liquid medium (Saparrat et al. 2000), might be immobilized in GP matrix and/or in fungal walls when cultured on SSF. Furthermore, these enzymes can be inhibited by the phenols available in the WSF from GP since previous data reported that lignocellulose substrates, including some from winemaking, and/or their phenols can inactivate extracellular laccases and MnPs (Ruiz et al. 2002, Skoronski et al. 2014). Since phenol reduction in WSF was observed for P. albobadia LPSC 285 and other fungi tested, polymerization of GP phenols mediated by the activity of extracellular laccases and/ or peroxidases cannot be discarded (Saparrat et al. 2010b). Furthermore, the action of other concomitant fungal mechanisms could also be involved in phenol content reduction, as previously suggested (de la Rubia et al. 2008). Since a higher reduction was found at 30 days, the phenol removal in WSF from GP could also involve non-enzymatic mechanisms. Mycelial adsorption has been involved in detoxification and/or decolorization reactions of chromophoric components, including those available in other phenol-rich organic residues such as those from fungal transformation of alpeorujo (Saparrat \& Hammer 2006, de la Rubia et al. 2008). Therefore, the decrease in sugars and free phenol content in the GP by $P$. albobadia LPSC 285 might be the results of a concerted action of both endoglucanase and 
oxidative non-enzymatic events. In addition, WSF can be used as a factor that indirectly reflects alteration of the insoluble lignocellulose macromolecular fractions (Dorado et al. 1999, Mallerman et al. 2018). Specifically, the $E_{4} / E_{6}$ ratio, measured by UV-VIS spectroscopy, has been used as an indicator of organic matter quality in WSF (Dorado et al. 1999, Saparrat et al. 2008). This ratio is considered to be inversely related to the degree of condensation and aromaticity of the chromophore substances and to their degree of humification/transformation (Stevenson 1994, Senesi et al. 2003). We found a higher $E_{4} / E_{6}$ ratio in WSF from fungal-treated GP after 30 and 60 days, which reflects a low degree of aromatization and presence of a relatively large proportion of aliphatic structures in organic compounds in WSF (Stevenson 1994). This suggests a dominance of soluble aliphatic chromophores, which are easily decomposable, as opposed to WSF from untreated GP, which is a source of molecules with a high degree of aromaticity and condensation that are harder to decompose. However, an opposite pattern was found after 90 days of incubation, possibly due to the C-demand of the fungus, which first used easily assimilable compounds and then led to the accumulation of products derived from lignin depolymerisation in WSF. Such events are accompanied by a high polydispersion, which implies a predominance of soluble compounds of low molecular weight that could be consumed by fungus and/or repolymerized during the conversion process. A similar pattern was observed during the transformation of rice straw in soil by Phanerochaete chrysosporium and Streptomyces badius (Huang et al. 2008), though the monitoring time was higher than that in our study.

\section{CONCLUSIONS}

We here showed the potential of $P$. albobadia LPSC \# 285 for treating GP from V. labrusca, the main solid waste generated from winemaking at "La Cooperativa de la Costa" in Argentina. This fungus transformed this residue, reducing its mass and soluble phenolic compounds. It metabolized simple sugar and soluble phenols and degraded polysaccharides available in this recalcitrant residue. Future studies are required to evaluate whether this fungus is also competitive on GP from other species of Vitis, such as V. vinifera, even under non-sterile conditions for large-scale applications, such as wineries.

\section{Acknowledgments}

We wish to thank Dr M Fernanda Rozas from INIFTA (CONICET-UNLP, La Plata, Argentina) for her assistance in performing the FTIR analysis. MIT is recipient of a scholarship from the UNLP. CBF and MEEF are recipients of a scholarship from the CONICET. MVM, MR and MCNS are members of the Research Career of CONICET, Argentina. $A B$ and $P A B$ are researchers from Comisión de Investigaciones Científicas de la Provincia de Buenos Aires (CICPBA), Argentina. This research was partially supported by Agencia Nacional de Promoción Científica y Tecnológica (PICT 2015-1620 to MCNS), CONICET (PUE INFIVE), CICPBA and UNLP, Argentina.

\section{REFERENCES}

ARCANJO NMO, NERI-NUMA IA, BEZERRA TK, DA SILVA FLH, PASTORE GM \& MADRUGA MS. 2017. Quality evaluation of red wines produced from the Isabella and Ives cultivar (Vitis labrusca): physicochemical parameters phenolic composition and antioxidant activity. Food Sci Technol (Campinas) 37: 184-192.

ARIENZO M, DE MARTINO A, CAPASSO R, DI MARO A \& PARENTE A. 2003. Analysis of carbohydrates and amino acids in vegetable waste waters by ion chromatograpy. Phytochem Anal 14: 74-82.

BATSOULIS AN, NACOS MK, PAPPAS CS, TARANTILIS PA, MAVROMOUSTAKOS T \& POLISSIOU MG. 2004. Determination of uronic acids in isolated hemicelluloses from 
Kenaf using Diffuse Reflectance Infrared Fourier Transform Spectroscopy (DRIFTS) and the Curve-Fitting Deconvolution Method. Appl Spectrosc 58: 199-202.

BOERIU CG, BRAVO D, GOSSELINK RJA \& VAN DAM JEG. 2004. Characterisation of structure-dependent functional properties of lignin with infrared spectroscopy. Ind Crops Prod 20: 205-218.

BOTELLA C, DIAZ A, DE ORY I, WEBB C \& BLANDINO A. 2007. Xylanase and pectinase production by Aspergillus awamori on grape pomace in solid state fermentation. process Biochem 42: 98-101.

BURG P, VÍTĚZ T, TURAN J \& BURGOVÁ J. 2014. Evaluation of grape pomace composting process. Acta Univ Agric Silvic Mendelianae Brun 62: 875-881.

BUSTAMANTE MA, MORAL R, PAREDES C, PÉREZ-ESPINOSA A, MORENO-CASELLES J \& PÉREZ-MURCIA MD. 2008. Agrochemical characterisation of the solid by-products and residues from the winery and distillery industry. Waste Manag 28: 372-380.

CARBALLO-MEILAN A, GOODMAN AM, BARON MG \& GONZALEZRODRIGUEZ J. 2014. A specific case in the classification of woods by FTIR and chemometric: Discrimination of Fagales from Malpighiales. Cellulose 21: 261-273.

DE LA RUBIA T, LUCAS M \& MARTÍNEZ J. 2008. Controversial role of fungal laccases in decreasing the antibacterial effect of olive mill waste-waters. Bioresour Technol 99: 1018-1025.

DIAZ MJ, MADEJÓN E, LÓPEZ F, LÓPEZ R \& CABRERA F. 2002. Optimization of the rate vinasse/grape marc for cocomposting process. Process Biochem 37: 1143-1150.

DOKKEN K, DAVIS LC, ERICKSON LE \& CASTRO S. 2002. Fourier-transform infrared spectroscopy as a tool to monitor changes in plant structure in response to soil contaminants. Proceedings-Water Res Technol 1-7.

DOMÍNGUEZ J, MARTÍNEZ-CORDEIRO H, ÁLVAREZ-CASAS M \& LORES M. 2014. Vermicomposting grape marc yields high quality organic biofertiliser and bioactive polyphenols. Waste Manag Res 32: 1235-1240.

DORADO J, ALMENDROS G, CAMARERO S, MARTÍNEZ AT, VARES T \& HATAKKA A. 1999. Transformation of wheat straw in the course of solid-state fermentation by four ligninolytic basidiomycetes. Enzyme Microb Technol 25: 605-612.

FERRER J, PÁEZ G, MÁRMOL Z, RAMONES E, CHANDLER C, MARÍN M \& FERRER A. 2001. Agronomic use of biotechnologically processed grape wastes. Bioresour Technol 76: 39-44.

GARCíA-LOMILLO J \& GONZÁLEZ-SAnjosé ML. 2017. Applications of wine pomace in the food industry: approaches and functions. Compr Rev Food Sci Food Saf 16: 3-22.

GUERRA-RIVAS C, GALLARDO B, MANTECÓN ÁR, DEL ÁLAMOSANZA M \& MANSO T. 2017. Evaluation of grape pomace from red wine by-product as feed for sheep. J Sci Food Agric 97: 1885-1893.

HEREDIA-GUERRERO JA, BENITEZ JJ, DOMÍNGUEZ E, BAYER IS, CINGOLANI R, ATHANASSIOU A \& HEREDIA A. 2014. Infrared and raman spectroscopic features of plant cuticles: a review. Front Plant Sci 5: 1-14.

HODGE A, ROBINSON D \& FITTER A. 2000. Are microorganisms more effective than plants at competing for nitrogen? Trends Plant Sci 5: 304-308.

HOOD IA, BEETS PN, GARDNER JF, KIMBERLEY MOM, POWER WP \& RAMSFIELD TD. 2008. Basidiomycete decay fungi within stems of Nothofagus windfalls in a Southern Hemisphere beech forest. Can J For Res 38: 1897-1910.

HUANG HL, ZENG GM, TANG L, YU HY, XI HM, CHEN ZM \& HUANG GH. 2008. Effect of biodelignification of rice straw on humification and humus quality by Phanerochaete chrysosporium and Streptomyces badius. Int Biodeter Biodegrad 61: 331-336.

IVANOVA-PETROPULOS V, HERMOSÍN-GUTIÉRREZ I, BOROS B, STEFOVA M, STAFILOV T, VOJNOSKI B, DÖRNYEI Á \& KILÁR F. 2015. Phenolic compounds and antioxidant activity of Macedonian red wines. J Food Compost Anal 41: 1-14.

JARVIS RM, BROADHURST D, JOHNSON H, O'BOYLE NM \& GOODACRE R. 2006. PYCHEM: A multivariate analysis package for python. Bioinformatics 22: 2565-2566.

KACURÁKOVÁ M, CAPEK P, SASINKOVÁ V, WELLNER N \& EBRINGEROVÁ A. 2000. FT-IR study of plant cell wall model compounds: pectic polysaccharides and hemicelluloses. Carbohydr Polym 43: 195-203.

KYOMUGASHO C, CHRISTIAENS S, SHPIGELMAN A, VAN LOEY AM \& HENDRICKX ME. 2015. FT-IR spectroscopy a reliable method for routine analysis of the degree of methylesterification of pectin in different fruit-and vegetable-based matrices. Food Chem 176: 82-90.

LEÃO DP, BOTELHO BG, OLIVEIRA LS \& FRANCA AS. 2018. Potential of pequi (Caryocar brasiliense Camb.) peels as sources of highly esterified pectins obtained by microwave assisted extraction. LWT - Food Sci Technol 87: 575-580.

LEVIN L, DIORIO L, GRASSI E \& FORCHIASSIN F. 2012. Grape stalks as substrate for white rot fungi lignocellulolytic enzyme production and dye decolorization. Rev Argent Microbiol 44: 105-112. 
MALLERMAN J, ITRIA R, ALARCÓN-GUTIÉRREZ E, HERNÁNDEZ C, LEVIN L \& SAPARRAT M. 2018. Exotic litter of the invasive plant Ligustrum lucidum alters enzymatic production and lignin degradation by selected saprotrophic fungi. Can J For Res 48: 709-720.

MAZA M, PAJOT HF, AMOROSO MJ \& YASEM MG. 2014. Post-harvest sugarcane residue degradation by autochthonous fungi. Int Biodeterior Biodegrad 87: 18-25.

NAUMANN D. 2000. Infrared spectroscopy in microbiology. In: Encyclopedia of analytical chemistry. Wiley, p. 102-131.

PANDEY KK \& PITMAN AJ. 2003. FTIR studies of the changes in wood chemistry following decay by brown-rot and white-rot fungi. Int Biodeterior Biodegrad 52: 151-160.

POPESCU CM, POPESCU MC \& VASILE C. 2010. Characterization of fungal degraded lime wood by FT-IR and 2D IR correlation spectroscopy. Microchem J 95: 377-387.

POPESCU CM, SINGUREL G, POPESCU MC, VASILE C, ARGYROPOULOS DS \& WILLFÖR S. 2009. Vibrational spectroscopy and $X$-ray diffraction methods to establish the differences between hardwood and softwood Carbohydr Polym 77: 851-857.

POPESCU CM, VASILE C, POPESCU MC \& SINGUREL G. 2006. Degradation of lime wood painting supports. II. Spectral characterization. Cellul Chem Technol 40: 649-658.

RAJCHENBERG M \& ROBLEDO GL. 2013. Pathogenic polypores in Argentina. Forest Pathol 43: 171-184.

RIZZON LA, MIELE A \& MENEGUZZO J. 2000. Evaluation of CV. Isabella and Ives elaborate red table wine. Food Sci Technol (Campinas) 20: 115-121.

ROCKENBACH II, GONZAGA LV, RIZELIO VM, DE SS GONÇALVES AE, GENOVESE MI \& FETT R. 2011. Phenolic compounds and antioxidant activity of seed and skin extracts of red grape (Vitis vinifera and Vitis labrusca) pomace from Brazilian winemaking. Food Res Int 44: 897-901.

ROSTAMI R. 2011. Chapter 8 - Vermicomposting. In: Kumar $S$ (Ed), Integrated Waste Management - Volume II, InTech, p. 131-142. Available from: http://www.intechopen. com/books/integrated-wastemanagementvolumeii/ vermicomposting.

RUIZ JC, DE LA RUBIA T, PEREZ I \& MARTINEZ LOPEZ J. 2002. Effect of olive oil mill wastewater on extracellular ligninolytic enzymes produced by Phanerochaete flavido-alba. FEMS Microbiol Lett 212: 41-45.

SÁNCHEZ A, YSUNZA F, BELTRÁN-GARCíA MJ \& ESQUEDA M. 2002. Biodegradation of viticulture wastes by Pleurotus: a source of microbial and human food and its potential use in animal feeding. J Agric Food Chem 50: 2537-2542.
SAPARRAT MCN, BUCSINSZKY AMM, TOURNIER HA, CABELLO MN \& ARAMBARRI AM. 2000. Extracellular ABTS-oxidizing activity of autochthonous fungal strains from Argentina in solid medium. Rev Iberoam Micol 17: 64-68.

SAPARRAT MCN, ESTEVEZ JM, TRONCOZO MI, ARAMBARRI AM \& BALATTI PA. 2010a. In-vitro depolymerization of Scutia buxifolia leaf-litter by a dominant Ascomycota Ciliochorella sp. Int Biodeterior Biodegrad 64: 262-266.

SAPARRAT MCN \& HAMMER E. 2006. Decolorization of synthetic dyes by the deuteromycete Pestalotiopsis guepinii CLPS no. 786 strain. J Basic Microbiol 46: 28-33.

SAPARRAT MCN, JURADO M, DÍAZ R, GARCIA-ROMERA I \& MARTÍNEZ MJ. 2010b. Transformation of the water soluble fraction from "alpeorujo" by Coriolopsis rigida: the role of laccase in the process and its impact on Azospirillum brasiliense survival. Chemosphere 78: 72-76.

SAPARRAT MCN, MARTINEZZ MJ, CABELLO MN \& ARAMBARRI AM. 2002. Screening for ligninolytic enzymes in autochthonous fungal strains from Argentina isolated from different substrata. Rev Iberoam Micol 19: 181-185.

SAPARRAT MCN, ROCCA M, AULICINO M, ARAMBARRI AM \& BALATTI PA. 2008. Celtis tala and Scutia buxifolia leaf litter decomposition by selected fungi in relation to their physical and chemical properties and lignocellulolytic enzyme activity. Eur J Soil Biol 44: 400-407.

SCHAFFER TK, WOHLENBERG MF, MEDEIROS N, MARTINS JB, AGOSTINI F, FUNCHAL C \& DANI C. 2016. Evaluation of antioxidant activity of grapevine leaves extracts (Vitis labrusca) in liver of Wistar rats. An Acad Bras Cienc 88: 187-196.

SCHWANNINGER M, RODRIGUES JC, PEREIRA H \& HINTERSTOISSER B. 2004. Effects of short-time vibratory ball milling on the shape of FT-IR spectra of wood and cellulose. Vib Spectrosc 36: 23-40.

SENESI N, D'ORAZIO V \& RICCA G. 2003. Humic acids in the first generation of Eurosoils. Geoderma 116: 325-344.

SKORONSKI E, FERNANDES M, MAGALHÃES MDLB, DA SILVA GF, JOÃO JJ, SOARES CHL \& JÚNIOR AF. 2014. Substrate specificity and enzyme recycling using chitosan immobilized laccase. Molecules 19 (10): 16794-16809.

SPERANZA M, GUTIÉRREZ A, DEL RÍO JC, BETTUCCI L, MARTÍNEZ ÁT \& MARTÍNEZ MJ. 2009. Sterols and lignin in Eucalyptus globulus Labill. wood: spatial distribution and fungal removal as revealed by microscopy and chemical analyses. Holzforschung 63: 362-370.

STEVENSON FJ. 1994. Humus chemistry: genesis, composition, reactions, $2^{\text {nd }}$ ed., New York: Wiley, 512 p. 
STUART BH \& ANDO DJ. 1997. Biological Applications of infrared spectroscopy, New York: J Wiley \& Sons, 212 p.

SYNYTSYA A, ČOPÍKOVÁ J, MATĚJKA P \& MACHOVIČ V. 2003. Fourier transform raman and infrared spectroscopy of pectins. Carbohydr Polym 54: 97-106.

TOALDO IM, FOGOLARI O, PIMENTEL GC, DE GOIS IS, BORGES DLG, CALIARI V \& BORDIGNON-LUIZ M. 2013. Effect of grape seeds on the polyphenol bioactive content and elemental composition by ICP-MS of grape juices from Vitis labrusca L. LWT - Food Sci Technol 53: 1-8.

VALLEJO MD, MARTín ML, MONETTA P \& GOUIRIC SC. 2012. Selection of relevant variables to the enzyme production on red grape pomace by solid-state fermentation. J Life Sci 6: 608-614.

VELARDE I, MUCHNIK J \& CITTADINI R. 2013. ¡Al gran Pueblo Argentino salud! El retorno del vino de la costa de Berisso. Rev Fac de Agronomía (La Plata) 112: 45-61.

\section{How to cite}

TRONCOZO MI, FIGOLI CB, FRANCO MEE, MIRÍFICO MV, BOSCH A, RAJCHENBERG M, BALATTI PA \& SAPARRAT MCN. 2020. Biotransformation of grape pomace from Vitis labrusca by Peniophora albobadia LPSC \# 285 (Basidiomycota). An Acad Bras Cienc 92: e20181174. DOI 10.1590/00013765202020181174.

Manuscript received on November 8, 2018; accepted for publication on December 14, 2018

\section{MARÍA I. TRONCOZO ${ }^{1}$}

https://orcid.org/0000-0001-9553-3093

\section{CECILIA B. FIGOLI ${ }^{2}$}

https://orcid.org/0000-0002-0287-2633

\section{MARIO E.E. FRANCO 3}

https://orcid.org/0000-0002-4959-1257

\section{MARÍA V. MIRÍFICO 4,5}

https://orcid.org/0000-0001-6093-2211

\section{ALEJANDRA BOSCH ${ }^{2}$}

https://orcid.org/0000-0002-8243-7577

\section{MARIO RAJCHENBERG ${ }^{6}$}

https://orcid.org/0000-0001-5031-5148

PEDRO A. BALATTII,3

https://orcid.org/0000-0002-5163-4084 https://orcid.org/0000-0001-7403-1713

${ }^{1}$ Cátedra de Microbiología Agrícola, Facultad de Ciencias Agrarias y Forestales, Universidad Nacional de La Plata, 60 y 119, 1900 La Plata, Argentina

${ }^{2}$ Laboratorio de Bioespectroscopía, Centro de Investigación y Desarrollo en Fermentaciones Industriales (CINDEFI), Facultad de Ciencias Exactas, Universidad Nacional de La Plata (UNLP)-CCT-La Plata-Consejo Nacional de Investigaciones Científicas y Técnicas (CONICET), Calle 50 Esquina 115, 1900 La Plata, Argentina.

${ }^{3}$ Centro de Fitopatología-CIDEFI, Facultad de Ciencias Agrarias y Forestales, Universidad Nacional de La Plata (UNLP)- CICBA, 60 y 119, CC31, 1900 La Plata, Argentina

${ }^{4}$ Instituto de Investigaciones Fisicoquímicas Teóricas y Aplicadas (INIFTA) Universidad Nacional de La Plata (UNLP)CCT-La Plata-Consejo Nacional de Investigaciones Científicas y Técnicas (CONICET), Diag. 113 y 64, 1900 La Plata, Argentina

${ }^{5}$ Facultad de Ingeniería, Departamento de Ingeniería Química, Universidad Nacional de La Plata, Calle 47 y 1, 1900 La Plata, Argentina

${ }^{6}$ Centro Forestal CIEFAP, C.C. 149200 Esquel, Chubut, Argentina ${ }^{7}$ Instituto de Fisiología Vegetal (INFIVE), Universidad Nacional de La Plata (UNLP)-CCT-La Plata-Consejo Nacional de Investigaciones Científicas y Técnicas (CONICET) Diag. 113 y 61, CC 327, 1900 La Plata, Argentina

${ }^{8}$ Instituto de Botánica Spegazzini, Facultad de Ciencias Naturales y Museo, Universidad Nacional de La Plata, 53 - 477, 1900 La Plata, Argentina

Correspondence to: Mario Carlos Nazareno Saparrat

E-mail:masaparrat@fcnym.unlp.edu.ar

\section{Author contributions}

MIT designed and performed experiments, analyzed data and co-wrote the manuscript. CBF and AB analyzed FT-IR data. MEEF helped performing different tasks in laboratory. MVM contributed to FT-IR sample preparation. MR provided fungal strains. PAB was involved in the analysis and discussion of the data obtained and assisted with the writing of the paper. MCNS supervised the research, provided funding acquisition and cowrote the paper.

\section{(cc) BY}

MARIO C. N. SAPARRAT ${ }^{1,7,8}$ 